\title{
Degradation of Oxytetracycline, Streptomycin, Sulphathiazole and Chloramphenicol Residues in Different Types of Honey
}

\author{
Milica Gačićn , Nina Bilandžićc Đurđica Ivanec Šipušić ${ }^{1}$, Marinko Petrović ${ }^{1}$ \\ Blaženka Kos ${ }^{3 *}$, Nada Vahčić ${ }^{3}$ and Jagoda Šušković ${ }^{3}$ \\ ${ }^{1}$ Food Control Centre, Faculty of Food Technology and Biotechnology, University of Zagreb, \\ Jagićeva 31, HR-10000 Zagreb, Croatia \\ ${ }^{2}$ Croatian Veterinary Institute, Savska cesta 143, HR-10000 Zagreb, Croatia \\ ${ }^{3}$ Faculty of Food Technology and Biotechnology, University of Zagreb, Pierottijeva 6, \\ HR-10000 Zagreb, Croatia
}

Received: October 7, 2014

Accepted: February 6, 2015

\begin{abstract}
Summary
Some of the most frequently used antibiotics in apiculture for the treatment of bacterial brood diseases are oxytetracycline, chloramphenicol, sulphathiazole and streptomycin. Therefore, the aim of this research is to determine the degradation kinetics of the residua these antibiotics leave behind in different types of honey stored in dark at $25^{\circ} \mathrm{C}$. The examined honey samples $(N=74)$ originating from the Croatian market had satisfactory physicochemical properties and pollen characteristics. Quantitative analyses of antibiotic residues were done using HPLC and ELISA methods. No antibiotic residues were found in any of the tested acacia, chestnut, floral, meadow and honeydew honey samples $(N=74)$. In the next step, each of the tested honey samples was supplemented with one of the following antibiotics (in $\mathrm{mg} / \mathrm{kg}$ ): oxytetracycline 10, chloramphenicol 200, sulphathiazole 200 or streptomycin 0.5 . Relatively high mass fractions of antibiotics have been added to the honey because the stability of each antibiotic is highly dependent on the spiked antibiotic mass fraction and also on its chemical structure. During a 6-month storage in the dark at $25^{\circ} \mathrm{C}$, the dynamics of degradation of the studied antibiotics was proven to differ dependent on the type of honey into which the antibiotic was added. The half-life of oxytetracycline in the acacia, floral, meadow and honeydew honey stored in the dark at $25^{\circ} \mathrm{C}$ was $15,16,17$ and 19 days, respectively, while in the chestnut honey the decomposition failed to be seen even after 60 days of storage. In all examined honey samples, the half-life of chloramphenicol and sulphathiazole was proven to be longer than 6 months. The fastest decomposition was seen of oxytetracycline added into the acacia honey, followed by streptomycin and sulphathiazole added into the same, while the longest decomposition delay was seen when chloramphenicol was added into the floral honey. According to the results obtained using a linear model of degradation kinetics, the longest oxytetracycline degradation was expected to occur in chestnut honey (116 days). Chloramphenicol and sulphathiazole are preserved the longest in floral (for 661 and 581 days, respectively) and streptomycin in meadow honey (for 321 days).
\end{abstract}

Key words: antibiotic residues, chloramphenicol, oxytetracycline, streptomycin, sulphathiazole, honey, antibiotic degradation 


\section{Introduction}

Because they pollinate a number of various plant species, honey bees (Apis mellifera) are essential for the maintenance of biodiversity and are therefore counted among insects of the outmost importance for the ecosystems (1). However, apiculture faces numerous challenges, including changes in agricultural practices, an extensive use of pesticides and an ever more frequent use of antibiotics administered to prevent bee infections caused by pathogenic microorganisms (2). Forsgren (2) reports about a broad spectrum of specific pathogens that affect bee colonies; bacteria, viruses, fungi and endogenous and exogenous parasites being among them. Some of these microorganisms are particularly harmful and can make bee colonies collapse. The showcase of such a severe brood disease is the European or the American foulbrood caused by two different bacterial species, Melissococcus plutonius and Paenibacillus larvae. In order to prevent or treat brood infections, beekeepers usually administer a broad spectrum of antibiotics to protect their hives; tetracycline, sulphonamide, streptomycin and chloramphenicol being the most frequently used (3). An inadequate antibiotic use or too short a post-treatment waiting period give rise to potential risks faced by the consumers $(4,5)$. The presence of antibiotic residua in honey is unfavourable due to their potential toxicity or allergic reactions that might be provoked in sensitive persons, as well as due to the facilitation of antibiotic resistance developed by causative pathogens (6). Antibiotic resistance represents a global public health problem due to the steadily rising number of resistant bacteria on the one hand, and the lack of antibiotics capable of efficiently treating infections caused by such multidrug resistant bacteria, on the other (7).

In view of the foregoing, this study aims at investigating the degradation dynamics of antibiotics most commonly used in apiculture settings (that is to say, oxytetracycline, streptomycin, chloramphenicol and sulphathiazole), added into acacia, chestnut, floral, meadow and honeydew honey. Based on the obtained results, the study also attempts to assess the timeframe within which consumers might be affected by antibiotic residua present in various honey samples.

\section{Material and Methods}

\section{Honey samples}

A total of 74 samples of various honey types originating from the Croatian market (acacia, chestnut, floral, meadow and honeydew) were collected and their physicochemical properties were analysed; in the later course, the selected samples were also subjected to pollen analysis.

In the first step, the presence of antibiotic residua in the collected honey samples was determined in total using the ELISA assay (MaxSignal ${ }^{\mathrm{TM}}$ Total Antibiotics in Honey Test Kit, BIOO Scientific Corp., Austin, TX, USA). In the next step, the presence of antibiotic residua in positive samples was corroborated using the confirmatory methods detailed in the following paragraphs of the Material and Methods section.
Further study course made use of a single sample of each studied honey type proven to be free from any antibiotic residua whatsoever. The selected samples were homogenised and supplemented with antibiotics most commonly used in apiculture settings, that is to say, oxytetracycline, sulphathiazole, chloramphenicol and streptomycin. Relatively high mass fractions of antibiotics were added to honey because the stability of each antibiotic is highly dependent on the spiked antibiotic mass fraction and also on its chemical structure. Antibiotics were added as follows (in mg/kg): oxytetracycline (OTC) 10, chloramphenicol (CAP) and sulphathiazole (STZ) 200, and streptomycin (STR) 0.5. Antibiotic solutions were prepared using the selected antibiotic standards and methanol as a solvent. The honey samples prepared as detailed above were monitored for antibiotic residue decomposition kinetics throughout a 6-month storage period in the dark at $25^{\circ} \mathrm{C}$, the initial rate of antibiotic decomposition in the honey thereby being used as the rationale guiding the subsequent sampling frequency.

\section{Physicochemical properties and pollen characteristics of the honey samples}

Water mass fraction (moisture) was measured by a refractometer using the AOAC Official Method 969.38 (8). Electrical conductivity was measured by a Mettler conductivity meter (Mettler-Toledo, LLC, Columbus, OH, USA) according to the method proposed by the International Honey Commission (IHC) (9). The mass fraction of total reducing sugars (AOAC Method 920.183), sucrose mass fraction (AOAC Method 920.184) and acidity (AOAC Method 962.19) were measured conformant to the AOAC Official Methods (10). Diastase and invertase activities, and hydroxymethylfurfural (HMF) and proline mass fractions were determined using the methods proposed by the IHC (9). Pollen analysis was carried out using the methods established by the IUBS International Commission of Bee Botany described by Louveaux et al. (11).

\section{Determination of oxytetracycline residua}

Tetracycline separation was carried out using a reversed-phase liquid chromatography modified by Viñas et al. (12). The preparation of samples for injection was simplified by adding $10 \mathrm{~mL}$ of acetonitrile/10 $\mathrm{mM}$ oxalic acid solution ( $\mathrm{pH}=3$ ) mixture into an investigated sample in the ratio of 20:80, so as to be able to skip the purification by solid phase extraction. A Thermo Scientific SpectraSYSTEM liquid chromatograph (Waltham, MA, USA) composed of a degasser, a P2000 pump, an AS1000 autosampler and a UV2000 detector was used. A 5- $\mu$ m particle Discovery ${ }^{\circledR}$ RP-Amide C16 HPLC column, $15 \mathrm{~cm} \times 2.1 \mathrm{~mm}$ i.d. (Supelco, Sigma-Aldrich Corp. St. Louis, MO, USA) was used in a gradient elution fashion. The mobile phase A was represented by $10 \mathrm{mM}$ oxalic acid solution ( $\mathrm{pH}=3$ ), while the mobile phase $\mathrm{B}$ was represented by $10 \mathrm{mM}$ oxalic acid solution $(\mathrm{pH}=3)$ and acetonitrile in the ratio of $88: 12$. An optimal gradient of $100 \%$ mobile phase A to 100 $\%$ mobile phase B in $15 \mathrm{~min}$, the return to $100 \%$ mobile phase $A$ in $1 \mathrm{~min}$ and a 6-min conditioning back to baseline were recorded, giving a running time of $22 \mathrm{~min}$ on the whole. Chromatography was carried out at room temperature, the mobile phase flow rate thereby being $1 \mathrm{~mL} /$ 
min. A volume of $20 \mu \mathrm{L}$ of the sample and calibration solutions was injected and the detection was carried out at $355 \mathrm{~nm}$. The linearity and repeatability of the method were proven to be satisfactory. As for OTC, the repeatability parameter (intermediate precision tested on the samples) was $2.2 \%$. The linearity parameter of calibration curves, the $\mathrm{R}^{2}$ correlation coefficient, established for OTC was 0.999 for the performance area of 0.002 to $0.006 \mathrm{~mL}$ of OTC per $\mathrm{mL}$ of solution.

\section{Determination of chloramphenicol and sulphathiazole residua}

Chloramphenicol and sulphathiazole residua were determined using a method modified according to Pule $e t$ al. (13). The residua present in the honey samples were extracted using methanol/water solution (40:60); the obtained extracts and calibration solutions were subsequently subjected to chromatography using an Agilent 1100 chromatograph (Agilent Technologies, Santa Clara, CA, USA) composed of a degasser, a binary pump, an autosampler, a heated column-accommodating compartment and a DAD detector. A 5- $\mu \mathrm{m}$ HyperClone ODS column, $250 \mathrm{~mm} \times 4.6 \mathrm{~mm}$ (Phenomenex, Torrance, CA, USA), was used in an isocratic elution fashion. As for sulphathiazole, the mobile phase was represented by methanol and water mixed in the ratio of 15:85, while in the case of chloramphenicol the two were mixed in the ratio of 40:60. Chromatography was carried out at room temperature, the mobile phase flow rate was $1 \mathrm{~mL} / \mathrm{min}$, with the detection of sulphathiazole at $281 \mathrm{~nm}$ and of chloramphenicol at $278 \mathrm{~nm}$. The linearity and repeatability of the method were proven to be satisfactory. The repeatability parameter (intermediate precision tested on the samples) was established to be $4.3 \%$ with chloramphenicol and $4.8 \%$ with sulphathiazole. The linearity parameter of calibration curves, the $\mathrm{R}^{2}$ correlation coefficient, determined for chloramphenicol was 0.9999 and for sulphathiazole 0.9983, both pertaining to the volume fraction span of 0.01 to 0.04 $\mathrm{mL} / \mathrm{mL}$.

\section{Competitive enzyme immunoassay used for the determination of streptomycin residua}

Determination of streptomycin residua in the honey samples was made using an enzyme immunoassay kit (Euro-Proxima, Arnhem, the Netherlands), a microtitre plate-based competitive enzyme immunoassay used for the screening and quantitative analysis of streptomycin and dihydrostreptomycin in milk, tissue, fat, serum, honey, royal jelly, egg and urine samples, employed strictly according to the manufacturer's instructions. The limit of detection of the method in question, established within the frame of the validation procedure, was $8.2 \mathrm{ng} / \mathrm{mL}$, while the limit of quantification equalled to $16.0 \mathrm{ng} / \mathrm{mL}$ of the honey (14).

\section{Statistical analysis}

Basic statistics (mean and standard deviation), one-way ANOVA, Tukey's honestly significant difference (HSD) test for unequal sample size, and the regression and correlation analysis were carried out using the STATISTICA v. 12.0 software (15).

\section{Results and Discussion}

\section{Physicochemical properties and pollen characteristics of the honey samples}

Within the first stage of this research, physicochemical analyses of 74 honey samples were carried out to verify their quality in line with the Ordinance on Honey adopted by the Republic of Croatia (16). The results obtained with the acacia, chestnut, floral, meadow and honeydew honey samples are shown in Table 1. Pursuant to the requirements stipulated under the Ordinance (16), each and every tested sample met the requirements respective of the water content ( $20 \%$ at the maximum), free acid content (up to $50 \mathrm{mmol} / \mathrm{kg}$ ), electrical conductivity (up to 0.8 $\mathrm{mS} / \mathrm{cm}$, except for honeydew and chestnut honey, in which cases it is $0.8 \mathrm{mS} / \mathrm{cm}$ at least), sucrose content (up to $5 \%$, except for the acacia honey, where up to $10 \%$ is allowed), and HMF content (up to $40 \mathrm{mg} / \mathrm{kg}$ ). Of note, the Ordinance on Honey (16) and the EU Directive 2001/110/ EC (17) both neglected to lay down the permissible proline content in honey.

The obtained results, shown in Table 1, speak in proof of the thesis suggested by Bogdanov et al. (18) that the content of water represents the most important parameter when it comes to honey fermentation and stability, since no spoilage had been witnessed throughout a year-long storage of all tested samples (data not shown). Acidity values obtained for the acacia honey within this study frame spanned from 5.02 to $17.93 \mathrm{mmol} / \mathrm{kg}$, which is lower than reported by Golob and Plestenjak (19), who claimed the acidity values for the same honey variety to be 24 $\mathrm{mmol} / \mathrm{kg}$ on average. The acidity values established for the studied floral and meadow honey spanned from 12.30 to $39.90 \mathrm{mmol} / \mathrm{kg}$, which is similar to the results reported by Šarić et al. (20).

Electrical conductivity of a honey depends on the concentration of mineral substances, organic acids, proteins and other complex substances such as sugars and polyols which, once in a water solution, decompose to ions and become electrical conductors. The aforementioned represents the criterion based on which nectar and honeydew honey can be mutually distinguished. According to Devillers et al. (21), the average electrical conductivity of acacia honey is $0.195 \mathrm{mS} / \mathrm{cm}$, which is similar to the results obtained in this study. As for the chestnut honey, electrical conductivity values established in this study are quite similar to those reported by Marini et al. (22) (1.48 $\mathrm{mS} / \mathrm{cm}$ on average), while those obtained for the floral honey resemble those reported by Popek (23) $(0.684 \mathrm{mS} /$ $\mathrm{cm}$ on average).

The average content of sucrose in the acacia honey was $1.2 \%$, which is less than in acacia honey originating from France, which contains $2.049 \%$ of sucrose on average (21). The sucrose content of $0.25 \%$ published by Devillers et al. (21) in French chestnut honey is lower than in the chestnut honey samples analysed in this study. The same applies for Italian chestnut honey (24), in which only $0.2 \%$ of sucrose was found. The average content of sucrose found in the floral honey in this study was $1.2 \%$, which is almost half of $2.19 \%$ reported in Polish floral honey (23). White (25) claims that lower sucrose content 
Table 1. Physicochemical parameters of the acacia, chestnut, floral, meadow and honeydew honey samples

\begin{tabular}{|c|c|c|c|c|c|c|c|c|c|}
\hline \multirow{2}{*}{$\begin{array}{l}\text { Honey } \\
\text { type }\end{array}$} & \multirow{2}{*}{$\frac{\omega \text { (water) }}{\%}$} & \multirow{2}{*}{$\frac{b(\text { free acid })}{\mathrm{mmol} / \mathrm{kg}}$} & \multirow{2}{*}{$\frac{\kappa}{\mathrm{mS} / \mathrm{cm}}$} & \multirow{2}{*}{$\begin{array}{c}\omega \text { (total } \\
\text { reducing } \\
\text { sugars) }\end{array}$} & \multirow{2}{*}{$\frac{\omega \text { (sucrose) }}{\%}$} & \multirow{2}{*}{$\frac{\omega \text { (proline) }}{\mathrm{mg} / \mathrm{kg}}$} & \multirow{2}{*}{$\frac{\omega(\mathrm{HMF})}{\mathrm{mg} / \mathrm{kg}}$} & \multirow{2}{*}{$\frac{\begin{array}{c}\text { Diastase } \\
\text { activity }\end{array}}{\mathrm{DN}}$} & \multirow{2}{*}{$\begin{array}{l}\begin{array}{c}\text { Invertase } \\
\text { activity }\end{array} \\
\text { IN }\end{array}$} \\
\hline & & & & & & & & & \\
\hline $\begin{array}{l}\text { Acacia } \\
(N=24)\end{array}$ & $(16.6 \pm 1.3)^{a}$ & $(9.5 \pm 3.4)^{\mathrm{a}}$ & $(0.2 \pm 0.0)^{\mathrm{a}}$ & $(68.7 \pm 2.2)^{a}$ & $(1.2 \pm 1.1)^{a}$ & $(236 \pm 100)^{a}$ & $(8.6 \pm 6.8)^{a}$ & $(7.3 \pm 3.4)^{\mathrm{a}}$ & $(7.8 \pm 4.5)^{\mathrm{a}}$ \\
\hline $\begin{array}{l}\text { Chestnut } \\
(N=12)\end{array}$ & $(17.4 \pm 1.1)^{\mathrm{a}}$ & $(12.3 \pm 4.0)^{\mathrm{a}}$ & $(1.6 \pm 0.2)^{\mathrm{bc}}$ & $(68.4 \pm 2.5)^{\mathrm{a}}$ & $(1.1 \pm 1.5)^{\mathrm{a}}$ & $(633 \pm 254)^{\mathrm{b}}$ & $(4.0 \pm 4.5)^{\mathrm{b}}$ & $(12.3 \pm 2.5)^{b}$ & $(18.2 \pm 4.0)^{\mathrm{b}}$ \\
\hline $\begin{array}{l}\text { Floral } \\
(N=21)\end{array}$ & $(17.0 \pm 1.3)^{\mathrm{a}}$ & $(22.4 \pm 6.7)^{\mathrm{b}}$ & $(0.6 \pm 0.2)^{\mathrm{b}}$ & $(68.8 \pm 1.9)^{\mathrm{a}}$ & $(1.2 \pm 0.9)^{\mathrm{a}}$ & $(596 \pm 339)^{\mathrm{b}}$ & $(9.7 \pm 5.2)^{\mathrm{a}}$ & $(11.9 \pm 4.0)^{\mathrm{b}}$ & $(15.0 \pm 8.7)^{\mathrm{b}}$ \\
\hline $\begin{array}{l}\text { Meadow } \\
(N=14)\end{array}$ & $(17.0 \pm 1.0)^{a}$ & $(23.7 \pm 8.0)^{\mathrm{b}}$ & $(0.4 \pm 0.2)^{\mathrm{b}}$ & $(70.0 \pm 1.9)^{a}$ & $(1.4 \pm 1.5)^{a}$ & $(683 \pm 304)^{\mathrm{b}}$ & $(10.7 \pm 7.1)^{\mathrm{a}}$ & $(10.7 \pm 2.8)^{\mathrm{b}}$ & $(14.6 \pm 10.9)^{\mathrm{b}}$ \\
\hline $\begin{array}{l}\text { Honeydew } \\
(N=3)\end{array}$ & $(16.0)^{a}$ & $(28.9)^{\mathrm{b}}$ & $(1.0)^{\mathrm{bcd}}$ & $(67.6)^{a}$ & $(1.0)^{\mathrm{a}}$ & $(703)^{b}$ & $(9.2)^{a}$ & - & $(14.0)^{\mathrm{ab}}$ \\
\hline
\end{tabular}

Mean values within each column with different letters in superscript are significantly different using Tukey's HSD test ( $\mathrm{p} \leq 0.05$ )

$\mathrm{DN}$ and IN=diastase and invertase number, respectively

should be attributed to diastase activity, which facilitates hydrolysis to monosaccharides whenever storage temperatures are somewhat higher; however, a sucrose unit and monosaccharides may also link together creating complex sugars, for instance trisaccharide melecitose.

Proline is the most dominant amino acid present in honey and serves as an indicator of honey maturity. According to Von der Ohe et al. (26), its mass fraction should not be allowed to drop below $180 \mathrm{mg} / \mathrm{kg}$. Costa et al. (27), who tested various nectar honey types originating from four Brazilian regions, reported that proline mass fractions widely differed, from 389 to $520 \mathrm{mg} / \mathrm{kg}$. Their findings suggest an intense bee activity in terms of nectar collecting and gland secretion. In light of the foregoing, the range of proline mass fractions established in chestnut, honeydew, floral and meadow honey in this study fits into the above higher mass fraction profile, while that obtained in the acacia honey is somewhat lower. According to Vahčić and Matković (28), the average mass fraction of proline was (in $\mathrm{mg} / \mathrm{kg}$ ): 184.6 in acacia, 381.4 in chestnut, 388.6 in honeydew, 461.2 in meadow and 351.4 in floral honey samples. As compared to the above results, the average proline mass fractions established in the same honey varieties were somewhat higher (Table 1).

Acacia belongs to plant species originally containing a low amount of diastase enzyme; as can be seen from the results obtained in this study, 9 out of 24 acacia honey samples displayed diastase activity lower than stipulated under the Ordinance (which is 8 diastase number (DN) for most of the honey varieties) (16). In such a case, the amount of HMF needs to be read off, and if lower than 15 $\mathrm{mg} / \mathrm{kg}$, the samples meet the requirements laid down under the Ordinance on Honey (16), as corroborated for the samples in this study (Table 1). Values obtained for French (23.29 DN) (21) and Italian honey (around $24 \mathrm{DN})(22,24)$ were somewhat higher than those obtained in our study. Diastase activity span established in this research resembles that reported by Costa et al. (27) for a total of 74 Brazilian herbal honey types (17.6 DN on average) and that reported by Al-Khalifa an Al-Arify (29) for ten Saudi honey varieties (from 16.7 to 76.7 IN). Serrano et al. (30) investigated the activity of invertase in citrus and eucalyptus honey and managed to prove the activity of the aforementioned enzyme to be lower in citrus honey, as was to be expected. Acacia honey also falls into the category of the the types of honey which, based on the research conducted insofar, display a lower enzymatic activity of both invertase and diastase as compared to other types of honey in this study.

Given that HMF represents an indicator of honey warming and freshness, low HMF values obtained in our research and shown in Table 1 indicate that the honey under study was fresh, i.e. that its enzyme levels are just as they should naturally be. Bogdanov (31) suggests that the mass fraction of HMF in a raw, unheated honey should be lower than $15 \mathrm{mg} / \mathrm{kg}$, while the invertase activity should surpass 10 invertase number (IN). According to Kahraman et al. (32), who tested a total of 70 honey samples originating from two Turkish regions, only two honey samples coming from retail chains failed to meet the HMF requirements.

Statistical analysis, which was performed using one-way ANOVA and Tukey's HSD test for unequal sample size, revealed that water and sucrose content, as well as the reducing sugars, did not differ significantly across the tested honey samples. The floral and the meadow honey are found to be similar when it comes to acidity values; nevertheless, the values of the latter significantly differ from those established in the acacia and the chestnut honey. The floral and the meadow honey also displayed no mutual differences in electrical conductivity values, as opposed to the other studied honey types that significantly differed in this parameter. Proline content, and diastase and invertase activities established in the acacia honey were significantly different from all the other honey types that were tested, being quite similar among themselves in this regard. HMF content found in the chestnut honey was significantly different from that of other studied honey types, which were quite similar in this regard as well.

In order to identify the botanical and geographical origin of a honey, one should conduct a pollen analysis in terms of the determination of representative pollen grain percentage. Pollen analyses conducted with each of the 
four honey samples (acacia, chestnut, floral and meadow) proved that the analysed samples genuinely belong to the variety declared on the label (Table 2).

When it comes to honeydew honey, no international qualitative and quantitative typing criteria have been adopted insofar, so that such a honey gets to be assessed based on the sensory analysis and electrical conductivity determination, as was done within this study frame (Table 1).

\section{Antibiotic residua in the honey samples}

Bees are exposed to a number of parasites and pathogens, the so-called American foulbrood and European foulbrood being the diseases of the most profoundly deleterious effect, widely spread and possibly lethal for the infected bee colonies. The diseases are caused by Paenibacillus larvae and Mellisoccocus plutonius bacteria (2,33), respectively, and are the reason why antibiotics have been widely used in apiculture settings despite of the ban on their use (34). Rapid immune affinity analyses used to screen 74 honey samples under this study have shown no antibiotic residua in any of them, so that no confirmatory methods had to be employed (data not shown). In order to improve the analytical methods used to identify oxytetracycline residua in honey, an extensive research has been conducted $(35,36)$, given that this antibiotic has been used to treat bee colonies ever since the 1950s (37). Due to its efficiency in containment of multi-drug resistant pathogens, CAP has often been used in veterinary medicine settings as well. However, due to its toxicity and possible cancerogenicity, CAP residua are not allowed to be pres- ent in food either in the US or in Europe, including Croatia (34). Streptomycin is an antibiotic falling into the class of aminoglycosides, reported by Wang et al. (38) to be fairly often used in apiculture settings. Van Bruijnsvoort et al. (39) analysed a total of 186 honey samples and reported that $26 \%$ of imported honey samples circulating on the Dutch market were streptomycin- and dihydrostreptomycin-positive. The results of this research on the presence of antibiotic residua in Croatian honey samples yielded values below those determined in the honey originating from Belgium (40) and Italy (41), in which 1 out of $7 \%$ of the tested samples came back streptomycin-, sulphonamide-, tetracycline-, tylosin- and chloramphenicol-positive. Recently, multiclass determination of 27 antibiotics in 74 honey samples of different botanical origins and geographical provenience collected from the Italian market confirmed only trace levels of sulfonamides, which do not raise concerns with respect to the public health, in 12 $\%$ of the examined honey samples (42). On the contrary, it must be emphasized that in the period from 2009 to 2013, more than $70 \%$ of notifications of the Rapid Alert System for Food and Feed (RASFF) from the European Commission reported the presence of antibiotic residues in honey bee products $(42,43)$.

\section{Degradation of antibiotic residua in the honey samples}

In this research, the dynamics of degradation of residua of four antibiotics (oxytetracycline, chloramphenicol, sulphathiazole and streptomycin) in honey samples was monitored throughout their storage in the dark at 25 ${ }^{\circ} \mathrm{C}$. According to a number of authors, the antibiotics chosen to be studied are most commonly used to prevent the

Table 2. Pollen types present in the honey samples

\begin{tabular}{|c|c|c|c|c|}
\hline \multirow{2}{*}{$\begin{array}{l}\text { Honey } \\
\text { type }\end{array}$} & \multicolumn{4}{|c|}{$N$ (samples) } \\
\hline & $\begin{array}{l}w(\text { predominant } \\
\text { pollen) }>45 \%\end{array}$ & $\begin{array}{l}w(\text { secondary pollen })= \\
16-45 \%\end{array}$ & $\begin{array}{l}w(\text { important minor } \\
\text { pollen) }=3-15 \%\end{array}$ & $w($ minor pollen $)<3 \%$ \\
\hline Acacia & Fagaceae 66 & Robinia pseudoacacia 20 & Rosaceae 3 & $\begin{array}{l}\text { Salix sp. 2, } \\
\text { Apiaceae, Asteraceae, Boraginaceae, } \\
\text { Brassicaceae, Cornaceae, Poaceae, } \\
\text { Tilia sp., Rhamnaceae }\end{array}$ \\
\hline Chestnut & Castanea sativa 95 & & & $\begin{array}{l}\text { Fabaceae } 1 \\
\text { Rosaceae } 1 \\
\text { Betulaceae } 1 \\
\text { Chenopodiaceae } 1 \\
\text { Rhamnaceae } 1\end{array}$ \\
\hline Floral & Fagaceae 45 & & $\begin{array}{l}\text { Fabaceae } 10 \\
\text { Rosaceae } 10 \\
\text { Brassicaceae } 7 \\
\text { Asteraceae } 6 \\
\text { Tilia sp. } 5 \\
\text { Poaceae } 3 \\
\text { Salix sp. } 3 \\
\text { Rhamnaceae } 3\end{array}$ & $\begin{array}{l}\text { Fabaceae } \\
\text { Violaceae } \\
\text { Cupressaceae } \\
\text { Lamiaceae }\end{array}$ \\
\hline Meadow & Fagaceae 65 & & $\begin{array}{l}\text { Rosaceae } 5 \\
\text { Asteraceae } 5 \\
\text { Brassicaceae } 4 \\
\text { Primulaceae } 4 \\
\text { Apiaceae } 3 \\
\text { Lamiaceae } 3 \\
\text { Robinia pseudoacacia } 3\end{array}$ & $\begin{array}{l}\text { Salix sp. } 2 \\
\text { Cornaceae } 2 \\
\text { Poaceae } 1 \\
\text { Alliaceae } 1 \\
\text { Fraxinus sp. } 1 \\
\text { Trifolium sp. } 1\end{array}$ \\
\hline
\end{tabular}


infection with Mellisoccocus plutonius and Paenibacillus larvae, i.e. pathogens causing the foulbrood disease (3). In view of the foregoing, more and more authors claim to have found the residua of these antibiotics in various honey samples, but the dynamics of their degradation has still remained mostly unknown $(40,42,44)$. The dynamics of degradation of oxytetracycline, chloramphenicol and sulphathiazole was approx. 20-70, 20-40 and $20 \%$ respectively, faster at 25 than at $15{ }^{\circ} \mathrm{C}$, in all five studied honey types (data obtained at $15{ }^{\circ} \mathrm{C}$ not shown). The results of Cara et al. (45) also showed streptomycin concentration to decrease in all honey samples over time and with temperature increase. We therefore chose to present the results of antibiotic degradation in honey stored at $25{ }^{\circ} \mathrm{C}$, i.e. at room temperature, at which honey is usually stored. Based on the obtained results, the dynamics of degradation of antibiotics under study followed various patterns dependent on the type of honey (Figs. 1-4). OTC half-life determined in four types of honey (acacia, honeydew, floral and meadow honey) stored in the dark at $25^{\circ} \mathrm{C}$ ranged from 21 to 25 days (Fig. 1), similar to the findings by Matsuka and Nakamura (46). The results obtained in this research for all four types of honey after a 60-day storage at room temperature resemble those reported by Peres at al. (47), who claimed the post 60-day storage amount of OTC

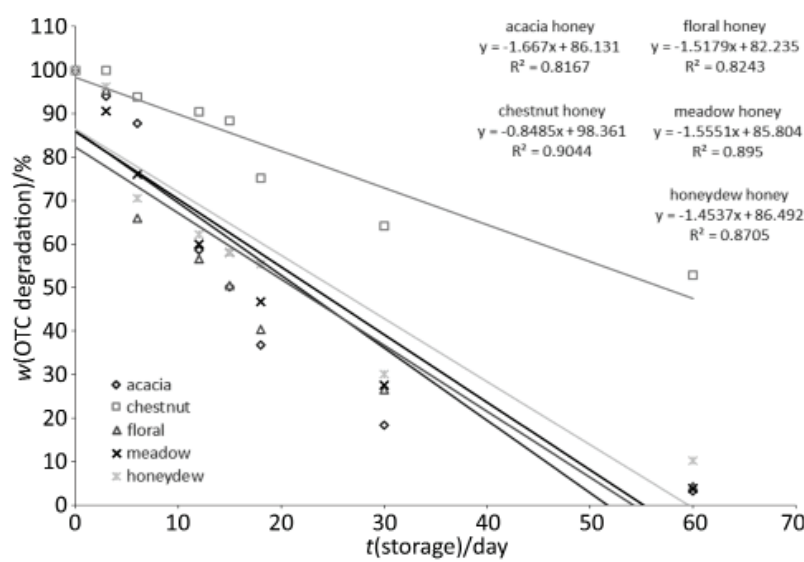

Fig. 1. Oxytetracycline (OTC) degradation in different types of honey observed during a 60 -day storage period at $25^{\circ} \mathrm{C}$

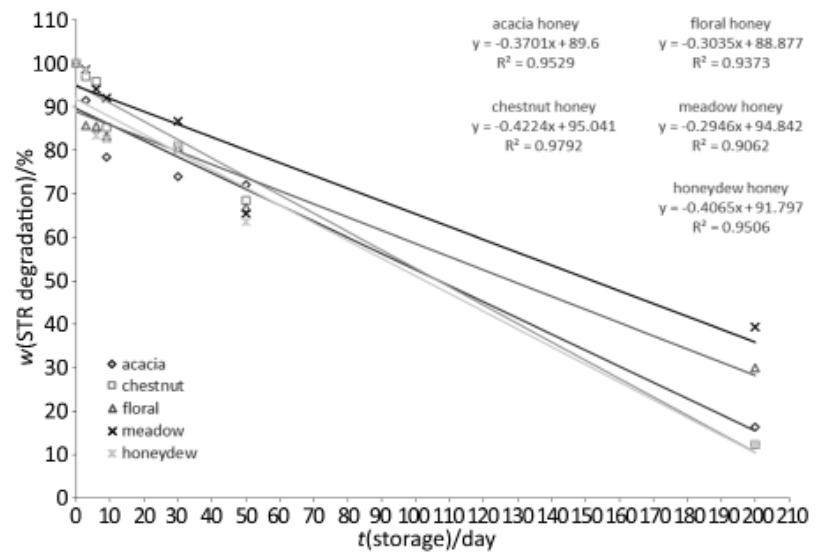

Fig. 2. Streptomycin (STR) degradation in different types of honey observed during a 200-day storage period at $25^{\circ} \mathrm{C}$ to be approx. $97 \%$ lower in all honey samples but the chestnut, in which OTC degraded more slowly, as proven also in this research, which showed OTC half-life in the chestnut honey to be 57 days. According to Čuláková et al. (44), OTC half-life determined in chestnut honey kept in the dark at $25.3^{\circ} \mathrm{C}$ was 77 days. However, Cara et al. (48) reported the tetracycline half-life in polyfloral and acacia honey to be 5 and 8 months, respectively. When discussing these results, one should bear in mind that honey represents a complex material harbouring various organic and inorganic substances capable of affecting OTC degradation kinetics. Various types of honey differ in their physicochemical parameters and in the representation of pollen grains coming from various plant species, the latter being dependent on the botanical origin of the tested honey (14). Kochansky et al. (49) suggested that the differences in OTC half-lives in various sugar solutions should be attributed to the impurities of mineral origin that contaminate such solutions.

The half-life of sulphathiazole and chloramphenicol was longer than 6 months in all of the examined types of honey (Figs. 3 and 4). The streptomycin and sulphathiazole degradation, seen during a 6-month storage at $25^{\circ} \mathrm{C}$, was almost equal in all honey types and was the slowest

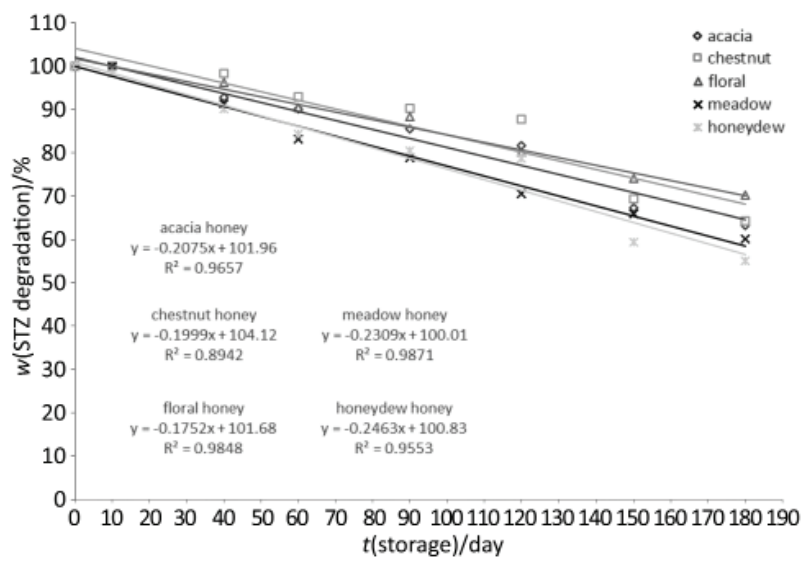

Fig. 3. Sulphathiazole (STZ) degradation in different types of honey observed during a 180 -day storage period at $25^{\circ} \mathrm{C}$

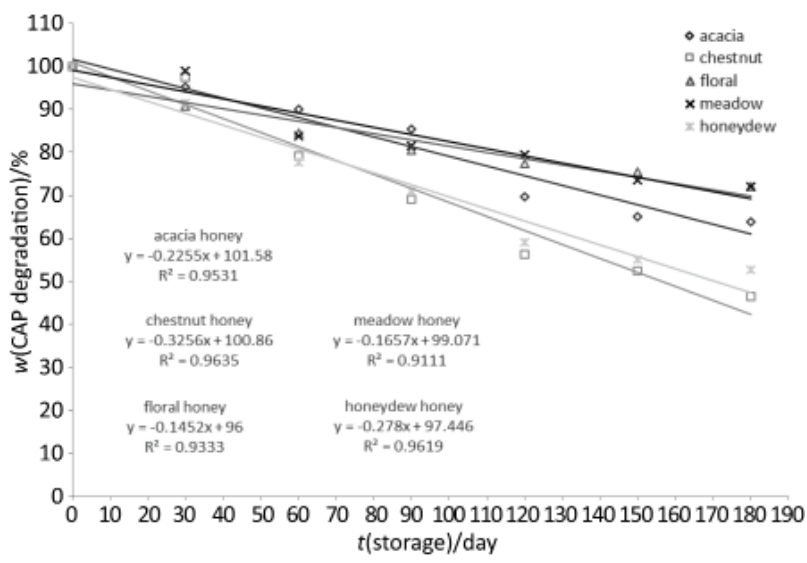

Fig. 4. Chloramphenicol (CAP) degradation in different types of honey observed during a 180 -day storage period at $25^{\circ} \mathrm{C}$ 
in the acacia and floral honey (Figs. 2 and 3). CAP decomposition was the slowest as compared to other antibiotics under study; nevertheless, honey type-based differences were observed as well. After 180 days of storage at room temperature, the fastest CAP decomposition was witnessed in the chestnut honey, while that in the floral and meadow honey was twice slower (Fig. 4).

Based on the OTC degradation established in this research and the data on the anticipated complete OTC degradation, obtained using a linear model descriptive of each honey type stored in a dark place at $25^{\circ} \mathrm{C}$, the anticipated time of complete OTC degradation in the acacia, floral, meadow and honeydew honey was quite similar (52-60 days) and twice faster than that expected in the chestnut honey (116 days) (Table 3$)$. On top of that, a huge difference in time needed for the complete CAP degradation was established across the studied honey varieties as well, that time being assessed at 22 months in the floral honey and at 10 to 12 months in the chestnut and honeydew honey (Table 3). Similar degradation time of CAP and other antibiotics observed in the floral and the meadow honey may be attributed to their kindred physicochemical properties as compared to other tested honey types (Table 1). Furthermore, total CAP decomposition time established in the floral and the meadow honey (2022 months) complies with the expiry date declared on the label (2 years), which is more than can be said for the chestnut, acacia and honeydew honey, in which complete CAP degradation time was calculated to be 10 to 15 months, hence putting the consumers at huge risk given that CAP residua should not be present in food, so that no maximum residue limits (MRLs) have been laid down. $\mathrm{CAP}$ amount has been defined by the minimum required performance limit (MRPL) at the level of $0.3 \mu \mathrm{g} / \mathrm{kg}$, since $\mathrm{CAP}$ affects the liver and the bone marrow, so that it has been banned from animal use both in the EU and in the US ever since 1994. Therefore, the development of sensitive and rapid methods to control and monitor CAP residua in food of animal origin, including honey, and the development of methods capable of removing CAP residua from honey are of current research interest $(50,51)$. Unfortunately, the European Community regulations neglected to lay down MRLs for antibiotics present in honey (2). Switzerland, UK and Belgium have enforced action limits of $0.01-0.05 \mathrm{mg}$ of antibiotic per $\mathrm{kg}$ of honey sample, so that any honey sample containing antibiotics at levels higher than the aforementioned is deemed noncompliant (3).

Table 3. The expected time of a complete degradation of oxytetracycline (OTC), streptomycin (STR), sulphathiazole (STZ) and chloramphenicol (CAP) residues in different types of honey stored at $25^{\circ} \mathrm{C}$. Data obtained using a linear mathematical model

\begin{tabular}{lrrrr}
\hline \multirow{2}{*}{$\begin{array}{l}\text { Honey } \\
\text { type }\end{array}$} & \multicolumn{4}{c}{$t$ (complete degradation of antibiotic residue)/day } \\
\cline { 2 - 5 } & OTC & CAP & STZ & STR \\
\hline Acacia & 52 & 451 & 492 & 242 \\
Chestnut & 116 & 310 & 521 & 225 \\
Floral & 54 & 661 & 581 & 293 \\
Meadow & 55 & 598 & 433 & 321 \\
Honeydew & 60 & 351 & 410 & 226 \\
\hline
\end{tabular}

Calculations of the time needed for a complete antibiotic degradation in various types of honey stored in the dark at $25{ }^{\circ} \mathrm{C}$ revealed CAP and sulphathiazole (STZ) to degrade slower than OTC and STR under the same conditions and in the same honey types (Table 3). The values descriptive of degradation dynamics of antibiotics under study are unbalanced since each of the tested honey samples represents a unique product having a number of inherent properties that differ from those of other tested samples. Given that correlation coefficients descriptive of the quantitative relationship between the time as an independent variable and the representation of antibiotic residua as a time-dependent variable obtained using the degradation kinetics model are strikingly high (0.9040.994) for each and every studied honey variety, the established degradation time can highly likely be considered accurate and should be viewed as a timeframe within which the consumption of antibiotic residue-contaminated honey can be risky for consumers.

To investigate if it is possible that some of the measured physicochemical parameters, which significantly differ in honey types, influence the degradation of antibiotics, linear correlation coefficients between physicochemical parameters (free acidity, electrical conductivity, proline and HMF content, diastase and invertase activities) of all honey types and the expected time for complete degradation of each antibiotic residue (oxytetracycline, streptomycin, sulphathiazole and chloramphenicol) were calculated. Obtained correlation coefficients represent a weak, moderate or strong, positive or negative correlation, which means that the examined physicochemical parameters of individual types of honey significantly affect degradation time of each individual antibiotic residue (Table 4). Oxytetracycline and chloramphenicol degradation is influenced in the highest degree by HMF content and electrical conductivity, while sulphathiazole and streptomycin degradation besides electrical conductivity and HMF content strongly depend on diastase activity and free acidity.

Table 4. Linear correlation coefficients between physicochemical parameters of all honey types and expected time for complete degradation of each antibiotic residua: oxytetracycline (OTC), streptomycin (STR), sulphathiazole (STZ) and chloramphenicol (CAP)

\begin{tabular}{|c|c|c|c|c|}
\hline \multirow[t]{2}{*}{$\begin{array}{l}\text { Physicochemical } \\
\text { parameters }\end{array}$} & \multicolumn{4}{|c|}{$\begin{array}{l}\text { Linear correlation coefficients in } \\
\text { relation to expected time for complete } \\
\text { degradation of antibiotic residua }\end{array}$} \\
\hline & OTC & CAP & STZ & STR \\
\hline Free acidity & -0.3997 & 0.2632 & -0.4342 & 0.3266 \\
\hline Electrical conductivity & 0.8944 & -0.6608 & 0.0606 & -0.5381 \\
\hline Proline content & 0.2606 & -0.0040 & -0.2648 & 0.2122 \\
\hline HMF content & -0.9465 & 0.7175 & 0.3083 & 0.6766 \\
\hline Diastase activity & 0.0517 & -0.4064 & -0.4840 & -0.3735 \\
\hline Invertase activity & 0.6756 & -0.1292 & 0.1629 & 0.0478 \\
\hline
\end{tabular}

HMF=hydroxymethylfurfural

\section{Conclusions}

Throughout a 6-month storage period in the dark at $25^{\circ} \mathrm{C}$, the degradation dynamics of the studied antibiotics 
(oxytetracycline, OTC; chloramphenicol, CAP; sulphathiazole, STZ and streptomycin, STR) took various courses in various honey types. OTC half-lives determined in four honey types (acacia, honeydew, floral and meadow honey), stored in the dark at room temperature, spanned from 15 to 19 days, while in the chestnut honey, OTC half-life failed to be attained even after 60 days of storage at $25^{\circ} \mathrm{C}$. The half-life of STZ and CAP was longer than 6 months in all examined honey types.

Calculations of the time needed for a complete degradation of antibiotics in various types of honey stored in the dark at $25{ }^{\circ} \mathrm{C}$ revealed CAP and STZ degradation to be slower as compared to that of OTC and STR under the same conditions and in the same honey types. The comparison of the decomposition dynamics and the anticipated time needed for a complete degradation of the studied antibiotics within the same honey variety brings us to the conclusion that the degradation dynamics is affected by two factors: the stability of the chemical structure of each antibiotic under concern, and differences in physicochemical properties between acacia, chestnut, floral, meadow and honeydew honey such as free acidity, electrical conductivity, diastase and invertase activities, and proline and hydroxymethylfurfural content.

\section{Acknowledgements}

This work was supported by the Croatian Ministry of Science, Education and Sports (Project grant no. 0580580696-2808).

\section{References}

1. Kropf U, Korošec M, Bertoncelj J, Ogrinc N, Nečemer M, Kump P, Golob T. Determination of the geographical origin of Slovenian black locust, lime and chestnut honey. Food Chem. 2010;121:839-46. http://dx.doi.org/10.1016/j.foodchem.2009.12.094

2. Forsgren E. European foulbrood in honey bees. J Invertebr Pathol. 2010;103:S5-9. http://dx.doi.org/10.1016/j.jip.2009.06.016

3. Al-Waili N, Salom K, Al-Ghamdi A, Ansari MJ. Antibiotic, pesticide, and microbial contaminants of honey: human health hazards. Sci World J. 2012; 2012:ID930849. http://dx.doi.org/10.1100/2012/930849

4. Leboš Pavunc A, Kos B, Beganović J, Uroić K, Bučan D, Šušković J. Antibiotic susceptibility and antimicrobial activity of autochthonous starter cultures as safety parameters for fresh cheese production. Mljekarstvo. 2013;63:185-94.

5. Makovec S, Kos B, Šušković J, Bilandžić N. Tetracycline antibiotics and determination of their residues in food. Croat J Food Technol Biotechnol Nutr. 2014;9:7-16 (in Croatian).

6. Džidić S, Šušković J, Kos B. Antibiotic resistance mechanisms in bacteria: biochemical and genetic aspects. Food Technol Biotechnol. 2008;46:11-21.

7. Lewis K. Platforms for antibiotic discovery. Nat Rev Drug Discov. 2013;12:371-87. http://dx.doi.org/10.1038/nrd3975

8. AOAC Official methods of analysis. 15th ed. Helrich K, editor. Arlington, VA, USA: AOAC International; 1990.

9. International Honey Commission (IHC). Harmonised Methods of the International Honey Commission; 2009.

http://www. bee-hexagon.net
10. AOAC Official Methods of Analysis. 13th ed. Horwitz W, editor. Washington, DC, USA: AOAC International; 1980.

11. Louveaux J, Maurizio A, Vorwohl G. Methods of melissopalynology. Bee World. 1978;59:139-57.

12. Viñas P, Balsalobre N, López-Erroz C, Hernández-Córdoba M. Liquid chromatography with ultravilet absorbance detection for the analysis of tetracycline residues in honey. J Chromatogr A. 2004;1022:125-29. http://dx.doi.org/10.1016/j.chroma.2003.09.066

13. Pule BO, Mmualefe LC, Toroto N. Determination of sulfonamide residues in chicken muscle by AgilentSampliQ QuEChERS AOAC kit and HPLC-FLD, Agilent Application Note, Food, Department of Chemistry Rhodes University, South Africa. http://www.agilent.com

14. Gačić M. Multi-screening approach to monitor and quantify some antibiotic residues in honey and the kinetic of degradation at various storage conditions [PhD Thesis]. Zagreb, Croatia: University of Zagreb; 2011 (in Croatian).

15. STATISTICA (Data Analysis Software System), v. 12, StatSoft, Inc, Tulsa, OK, USA; 2012. www.statsoft.com.

16. Ordinance on honey No. 93/09. Official Gazette of the Republic of Croatia; 2009 (in Croatian).

17. EU Council Directive 2001/110/EC of 20 December 2001 relating to honey. Off J Eur Commun. 2002; L10:47-52.

18. Bogdanov S, Lüllmnn C, Martin P. Honey quality, methods of analysis and international regulatory standards: Review of the work of the International Commission. Mitt Lebensm Hyg. 1999;90:108-25.

19. Golob T, Plestenjak A. Quality of Slovene honey. Food Technol Biotechnol. 1999;37:195-201.

20. Šarić G, Matković D, Hruškar M, Vahčić N. Characterization and classification of Croatian honey by physicochemical parameters. Food Technol Biotechnol. 2008;46:355-67.

21. Devillers J, Morlot M, Pham-Delegue MH, Dore JC. Classification of monofloral honeys based on their quality control data. Food Chem. 2004;86:305-12. http://dx.doi.org/10.1016/j.foodchem.2003.09.029

22. Marini F, Magri AL, Balestrieri F, Fabretti F, Marini D. Supervised pattern recognition applied to the discrimination of the floral origin of six types of Italian honey samples. Anal Chim Acta. 2004;515:117-25. http://dx.doi.org/10.1016/j.aca.2004.01.013

23. Popek S. A procedure to identify a honey type. Food Chem. 2002;79:401-6. http://dx.doi.org/10.1016/S0308-8146(02)00391-6

24. Persano Oddo L, Piro R. Main European unifloral honeys: descriptive sheets. Apidologie. 2004;35:Suppl.1.38-81.

25. White JW. Quality evaluation of honey: role of HMF and diastase assays. Am Bee J. 1992;132:737-43,792-4.

26. von der Ohe W, Dustmann JH, von der Ohe K. Proline as a criterion of honey maturity. Dtsch Lebensm Rundsch. 1991; 87:383-6 (in German).

27. Costa LSM, Albuquerque MLS, Trugo LC, Quinteiro LMC, Barth OM, Ribeiro M, De Maria CAB. Determination of nonvolatile compounds of different botanical origin Brazilian honeys. Food Chem. 1999;65:347-52. http://dx.doi.org/10.1016/S0308-8146(98)00230-1

28. Vahčić N, Matković D. Chemical, physical and sensory properties of honey. [Internet] 2009. http://www.pcelinjak.hr/index.php/Prehrana-i-biotehnologija/kemijske-fizikalne-i-senzorske-znaajke-med.html/ (in Croatian).

29. Al-Khalifa AS, Al-Arify LA. Physicochemical characteristics and pollen spectrum of some Saudi honeys. Food Chem. 1999;67:21-5. http://dx.doi.org/10.1016/S0308-8146(99)00096-5

30. Serrano S, Villarejo M, Espejo R, Jordal M. Chemical and physical parameters of Andalusian honey: classification of 
Citrus and Eucalyptus honeys by discriminaton analysis. Food Chem. 2004;87:619-25. http://dx.doi.org/10.1016/j.foodchem.2004.01.031

31. Bogdanov S. Harmonised Methods of the International Honey Commission, International Honey Commission (IHC); 2002. pp. 1-62.

32. Kahraman T, Buyukunal SK, Vural A, Alkunatmaz SS. Physico-chemical properties in honey from different regions of Turkey. Food Chem. 2010;123:41-4. http://dx.doi.org/10.1016/j.foodchem.2010.03.123

33. Genersch E. American foulbrood in honeybees and its causative agent Paenibacillus larvae. J Invertebr Pathol. 2010;103: S10-9. http://dx.doi.org/10.1016/j.jip.2009.06.015

34. EC: Council Regulation 37/2010/EU of 22 December 2009 on pharmacologically active substances and their classification regarding maximum residue limits in foodstuffs of animal origin. Off J Eur Commun. 2010;L15:1-72.

35. Wang LF, Peng JD, Liu LM. A reversed-phase high performance liquid chromatography coupled with resonance Rayleigh scattering detection for the determination of four tetracycline antibiotics. Anal Chim Acta. 2008;630:101-6. http://dx.doi.org/10.1016/j.aca.2008.09.066

36. Jing T, Gao XD, Wang P, Wang Y, Lin YF, Hu XZ, et al. Determination of trace tetracycline antibiotics in foodstuffs by liquid chromatography-tandem mass spectrometry coupled with selective molecular-imprinted solid-phase extraction. Anal Bioanal Chem. 2009;393:2009-18. http://dx.doi.org/10.1007/s00216-009-2641-z

37. Thompson HM, Waite RJ, Wilkins S, Brown MA, Bigwood T, Marvin Shaw M, Ridgway C, Sharman B. Effects of European foulbrood treatment regime on oxytetracycline levels in honey extracted from treated honeybee (Apis mellifera) colonies and toxicity to brood. Food Addit Contam Part A: Chem Anal Control Expo Risk Assess. 2005;22:573-8.

38. Wang S, Zhang HY, Wang L, Duan ZJ, Kennedy I. Analysis of sulphonamide residues in edible animal products: a review. Food Addit Contam. 2006;23:362-84. http://dx.doi.org/10.1080/02652030500499359

39. Van Bruijnsvoort M, Ottink SJM, Jonker KM, de Boer E. Determination of streptomycin and dihydrostreptomycin in milk and honey by liquid chromatography with tandem mass spectrometry. J Chromatogr. 2004;1058:137-42. http://dx.doi.org/10.1016/S0021-9673(04)01307-X

40. Reybroeck W, Ooghe S. Presence of antibiotics and chemotherapeutics in honey on the European market: situation in
2009. 4th European Conference of Apidology, EurBee 2010, Ankara, Turkey; 2010.

41. Baggio A, Gallina A, Benetti C, Muttinelli F. Residues of antibacterial drugs in honey on Italian market. Food Addit Contamin Part B. 2009;2:52-8.

42. Galarini R, Saluti G, Giusepponi D, Rossi R, Moretti S. Multiclass determination of 27 antibiotics in honey. Food Contr. 2015;48:12-24. http://dx.doi.org/10.1016/j.foodcont.2014.03.048

43. RASFF Portal. Online searchable database. http://ec.europa. eu/food/food/rapidalert/rasff_portal_database_en.htm

44. Čuláková V, Kiss E, Kubincová J, Šilhár S. Kinetics of degradation of oxytetracycline and tetracycline in honey and in a glucose-fructose model mixture in various storage condition. J Food Nutr Res. 2008;47:139-43.

45. Cara MC, Dumitrel GA, Glevitzky M, Mischie C, Silaghi-Perju D. Thermal degradation of streptomycin residues in honey during storage. Food Technol Biotechnol. 2013;51:31326.

46. Matsuka M, Nakamura J. Oxytetracycline residues in honey and royal jelly. J Apic Res. 1990;29:112-7.

47. Peres GT, Rath S, Reyes FGR. A HPLC with fluorescence detection method for the determination of tetracyclines residues and evaluation of their stability in honey. Food Contr. 2010;21:620-5. http://dx.doi.org/10.1016/j.foodcont.2009.09.006

48. Cara MC, Dumitrel GA, Glevitzky M, Perju D. Stability of tetracycline residues in honey. J Serb Chem Soc. 2012;77: 879-86. http://dx.doi.org/10.2298/JSC111002214C

49. Kochansky J, Knox D, Shimanuki H. Comparative stability of oxytetracycline and tylosin in sugar syrup. Apidologie. 1999; 30:321-6. http://dx.doi.org/10.1051/apido:19990408

50. Chen L, Li B. Magnetic molecularly imprinted poymer extraction of chloramphenicol from honey. Food Chem. 2013; 141:23-8. http://dx.doi.org/10.1016/j.foodchem.2013.02.085

51. Cheng N, Gao H, Deng J, Wang B, Xu R, Cao W. Removal of chloramphenicol by macroporous adsorption resins in honey: a novel approach on reutilization of antibiotics contaminated honey. J Food Sci. 2012;77:T169-72. http://dx.doi.org/10.1111/j.1750-3841.2012.02868.x 